\title{
Enhanced Strength and Corrosion Resistance of Mg-2Zn-0.6Zr Alloy with Extrusion
}

\author{
Luan-Xiang Wang ${ }^{1} \cdot$ Ren-Bo Song ${ }^{1} \cdot$ Chang-Hong Cai ${ }^{1}$ Jing-Yuan $\mathrm{Li}^{1}$
}

Received: 8 May 2018/Revised: 5 June 2018/Published online: 17 August 2018

(C) The Chinese Society for Metals and Springer-Verlag GmbH Germany, part of Springer Nature 2018

\begin{abstract}
The microstructure, mechanical properties and corrosion behavior of $\mathrm{Mg}-2 \mathrm{Zn}-0.6 \mathrm{Zr}$ alloy under the as-cast and asextruded conditions were investigated. Microstructure analysis indicated the remarkable grain refinement by extrusion, as well as notable reductions in volume fraction and size of precipitate phases. As compared with the as-cast alloy, the asextruded alloy exhibited better mechanical performance, especially in yield strength which was promoted from 51 to $194 \mathrm{MPa}$. Refined grains, dispersive precipitate phases and texture were thought to be the main factors affecting the improved performance in strength. The electrochemical measurement and immersion test revealed the corrosion rate of $\mathrm{Mg}-2 \mathrm{Zn}-0.6 \mathrm{Zr}$ alloy by extrusion decreased from 1.68 to $0.32 \mathrm{~mm} / \mathrm{year}$. The reasons for the enhanced corrosion resistance were mainly attributed to the decreased volume fraction and Volta potential of the precipitate phases, the refinement of the grain size, as well as the formation of more protective corrosion film.
\end{abstract}

Keywords $\mathrm{Mg}-2 \mathrm{Zn}-0.6 \mathrm{Zr} \cdot$ Extrusion $\cdot$ Strength $\cdot$ Corrosion behavior

\section{Introduction}

Magnesium alloys have attracted growing attention as a promising candidate for implant biomaterials in recent years [1]. The superiority lies in the following aspects. First, magnesium alloys have low density and elastic modulus similar to those of natural bone, which is conducive to avoiding stress shielding caused by a strong mismatch in elastic modulus between the implant metals and natural bone [2]. In addition, unlike traditional implanted materials comprising $\mathrm{Ti}$ alloys and stainless steels, magnesium alloys can naturally degrade and be absorbed in human body environment without a risky second operation for removal [3, 4]. Moreover, magnesium acts as an essential trace element in human body and involves in human metabolic activities [5], guaranteeing the safety of implants for human health. However, the shortcoming that magnesium alloys are highly susceptible

Available online at http://link.springer.com/journal/40195

Ren-Bo Song

songrb@mater.ustb.edu.cn

1 School of Materials Science and Engineering, University of Science and Technology Beijing, Beijing 100083, China to corrosion enormously restricts their practical application as biomedical implants [3]. Therefore, development of $\mathrm{Mg}$ alloys with excellent mechanical properties and high corrosion resistance is of great significance. Trace additions of alloying elements have been regarded as one of the most effective ways to enhance both strength and corrosion resistance.

In previous studies [6, 7], Mg-Al-based alloys have been zealously researched for their potential in medical use, but it turned out to be a letdown. Some alloys containing aluminum provided favorable corrosion resistance, but the neurotoxicity produced by aluminum was hazardous to human body [8]. Analogously, rare-earth (RE) elements may also induce latent toxic effects on human body [9]. Thus, the nontoxicity in biology should be paid much attention. According to the exploration of Song [10], some magnesium alloys containing $\mathrm{Ca}, \mathrm{Zn}$ and $\mathrm{Mn}$ may be the befitting candidates. Therein, $\mathrm{Mg}-\mathrm{Zn}$-based alloys were widely studied [11-14] and they exhibited less toxicity compared to $\mathrm{Mg}-\mathrm{Al}$ and $\mathrm{Mg}-\mathrm{RE}$ alloys. Cai et al. [11] found that the precise control of $\mathrm{Zn}$ addition contributes to promoting both mechanical properties and corrosion resistance of $\mathrm{Mg}$ alloys. In addition, trace addition of $\mathrm{Zr}$ element to $\mathrm{Mg}-\mathrm{Zn}$-based alloys can also reinforce their properties by refining the grain size and purifying $\mathrm{Mg}$ 
alloys after the removal of precipitation of $\mathrm{Fe}_{2} \mathrm{Zr}$ and $\mathrm{FeZr}_{2}$ from alloy melt [15]. And the biocompatibility of trace amount of $\mathrm{Zr}$ in human body environment has been proven already [16]. Lots of technological means, like coating [17], heat treatment [18], addition of more elements [19], laser rapid solidification [20], have been taken to further enhance the comprehensive properties of $\mathrm{Mg}-\mathrm{Zn}-\mathrm{Zr}$ alloy. Apart from the above means, extrusion is also considered as one available method for properties enhancement. Extensive studies [21-24] have proved that the extruded $\mathrm{Mg}$ alloys exhibit outstanding mechanical properties and corrosion resistance.

In this work, the $\mathrm{Mg}-2 \mathrm{Zn}-0.6 \mathrm{Zr}$ alloys under the as-cast and as-extruded conditions were fabricated. The effect of extrusion on the mechanical properties and corrosion resistance of alloys in Hank's solution was systematically studied. Moreover, the relationship between the microstructure and strength/corrosion, the protectiveness of corrosion film and the corrosion mechanism were investigated to gain in-depth understanding on corrosion behavior of $\mathrm{Mg}$ alloys.

\section{Materials and Methods}

\subsection{Alloy Preparation}

Alloy ingots with nominal composition of $\mathrm{Mg}-2 \mathrm{Zn}-0.6 \mathrm{Zr}$ were prepared from high-purity $\mathrm{Mg}$ (99.99 wt\%), highpurity Zn (99.99 wt\%) and Mg-30Zr (wt\%) master alloys. All the ingots were melted in a vacuum induction furnace at $780{ }^{\circ} \mathrm{C}$ and maintained for 30 min under the protective argon gas. Then, the molten alloy was poured into a preheated steel mold with a diameter of $70 \mathrm{~mm}$ to form cylinder-shaped ingots. Parts of the alloy ingots were extruded at $350{ }^{\circ} \mathrm{C}$ with an extrusion rate of $16: 1$ at a constant speed of $3 \mathrm{~mm} / \mathrm{s}$. Before extrusion, these ingots were subjected to solution treatment at $400{ }^{\circ} \mathrm{C}$ for $12 \mathrm{~h}$ and subsequently quenched in hot water at $60{ }^{\circ} \mathrm{C}$. The chemical composition of the alloys was determined by using inductively coupled plasma atomic emission spectroscopy (ICP-AES), as listed in Table 1.

\subsection{Microstructure Characterization}

The samples for microstructure observation were successively ground to 4000 grits with $\mathrm{SiC}$ abrasive papers, followed by ultrasonic cleaning in acetone and ethanol. After these, the samples were etched with a mixture consisting of $5 \mathrm{~g}$ picric acid, $10 \mathrm{~mL}$ acetic acid, $10 \mathrm{~mL}$ distilled water and $100 \mathrm{~mL}$ ethanol. Microstructures of the ascast and as-extruded alloys were observed by optical microscopy (OM) and scanning electron microscope (FESEM, FEI Quanta FEG 450) equipped with an energydispersive X-ray spectroscope (EDS). The grain size of the samples was determined by using an average linear intercept method. X-ray diffraction (XRD, Cu target, $20 \mathrm{kV}$ ) was conducted to analyze the intermetallic phases and micro-texture. The sample for texture measurement was cut from center of the as-extruded alloy and sectioned perpendicular to the extrusion direction (ED). In addition, the Volta potential difference between the precipitate phases and matrix was measured by atomic force microscopy (AFM, Dimension Icon) in tapping mode (SKPFM).

\subsection{Mechanical Test}

Tension test was performed for $\mathrm{Mg}-2 \mathrm{Zn}-0.6 \mathrm{Zr}$ alloys (ascast and as-extruded) in accordance with tensile test standard (GB/T228-2002) with a universal tensile testing machine (CM 75105) at room temperature. The specimens with a gage length of $25 \mathrm{~mm}$ and a gage diameter of $5 \mathrm{~mm}$ were used for the tension test.

\subsection{Electrochemical Measurement}

The corrosion properties of the as-cast and as-extruded alloys were evaluated by electrochemical measurement and immersion test. Samples for electrochemical measurement were sealed by epoxy with an exposed area of $1 \mathrm{~cm}^{2}$ after successively grinding to 4000 grits and cleaning. The measurement was carried out on an electrochemical workstation (Princeton Versa STAT MC) equipped with a classical three-electrode cell, including an alloy sample as working electrode, a saturated calomel electrode as reference electrode and a platinum electrode as auxiliary electrode. During the measurement, the samples were immersed in a beaker containing $400 \mathrm{~mL}$ Hank's solution at $37 \pm 0.5{ }^{\circ} \mathrm{C}$. A steady open circuit potential $\left(E_{\mathrm{OCP}}\right)$ was obtained after about 30-min immersion. Then, the potentiodynamic polarization scanning was performed at a rate of $5 \mathrm{mV} / \mathrm{s}$ over a potential range from $-2.1 \mathrm{~V}_{\mathrm{SCE}}$ to $-1.1 \mathrm{~V}_{\mathrm{SCE}}$. The obtained results were derived by Tafel extrapolation method. Afterward, the electrochemical
Table 1 Nominal and analyzed compositions of $\mathrm{Mg}-\mathrm{Zn}-\mathrm{Zr}$ alloys (wt $\%$ )

\begin{tabular}{llllllll}
\hline Alloy & $\mathrm{Zn}$ & $\mathrm{Zr}$ & $\mathrm{Fe}$ & $\mathrm{Ni}$ & $\mathrm{Cu}$ & $\mathrm{Al}$ & $\mathrm{Mg}$ \\
\hline Nominal composition & 2.00 & 0.60 & - & - & - & - & Bal. \\
Analyzed composition & 1.87 & 0.54 & $<0.01$ & $<0.01$ & $<0.01$ & 0.060 & Bal. \\
\hline
\end{tabular}


impedance spectroscopy (EIS) test was performed in open circuit potential by applying a sinusoidal potential of $10 \mathrm{mV}$ in the frequency range from $100 \mathrm{kHz}$ to $10 \mathrm{mHz}$. The obtained results were analyzed by using the ZsimpWin software.

\subsection{Immersion Test}

In accordance with the ASTM G31-72 standard, throughout the process of immersion test, the samples were immersed in beakers containing Hank's solution, with all the beakers sealed and incubated at $37 \pm 0.5{ }^{\circ} \mathrm{C}$ in a water bath. The samples of $\emptyset 11 \times 5 \mathrm{~mm}$ in size were ground to 4000 grits and cleaned until no evident defect and scratch could be noticed. Hank's solution was prepared with distilled water and high-purity chemicals, composed of $8.0 \mathrm{~g} /$ $\mathrm{L} \mathrm{NaCl}, 0.4 \mathrm{~g} / \mathrm{L} \mathrm{KCl}, 0.14 \mathrm{~g} / \mathrm{L} \mathrm{CaCl} 2,0.35 \mathrm{~g} / \mathrm{L} \mathrm{NaHCO}$, $0.1 \mathrm{~g} / \mathrm{L} \quad \mathrm{MgCl}_{2} \cdot 6 \mathrm{H}_{2} \mathrm{O}, 0.06 \mathrm{~g} / \mathrm{L} \quad \mathrm{MgSO}_{4} \cdot 7 \mathrm{H}_{2} \mathrm{O}, 0.06 \mathrm{~g} / \mathrm{L}$ $\mathrm{KH}_{2} \mathrm{PO}_{4}, 0.06 \mathrm{~g} / \mathrm{L} \mathrm{Na}_{2} \mathrm{HPO}_{4} \cdot 12 \mathrm{H}_{2} \mathrm{O}$ and $1.0 \mathrm{~g} / \mathrm{L} \mathrm{C}_{6} \mathrm{H}_{12} \mathrm{O}_{6}$. And the $\mathrm{pH}$ value of the solution was adjusted to 7.4 at $37 \pm 0.5{ }^{\circ} \mathrm{C}$ with $\mathrm{NaOH}$ solution. In particular, the ratio of the solution volume to the samples surface area was designated as $30 \mathrm{~mL} / \mathrm{cm}^{2}$ after reference to standards. To simulate the metabolic environment of human body, the solution for immersion was renewed every $24 \mathrm{~h}$. After the immersion, the samples were cleaned with distilled water and ethanol and then dried in cold flowing air. The morphology and composition of the corrosion products were characterized by SEM and XRD, respectively. For corrosion morphology observation, a mixture of $\mathrm{CrO}_{3}(200 \mathrm{~g} / \mathrm{L})$ and $\mathrm{AgNO}_{3}(10 \mathrm{~g} / \mathrm{L})$ was used to get rid of the corrosion products [2]. Laser scanning confocal microscopy (LSCM, Olympus LEXT OLS4100) was used to characterize the three-dimensional (3D) morphologies of tested alloys after removing corrosion products. The dried samples were weighed with an electronic balance before and after immersion, and the corrosion rates were calculated by weight loss measurement [25].

\section{Results}

\subsection{Microstructure}

Figure 1 shows the optical micrographs and SEM images of $\mathrm{Mg}-2 \mathrm{Zn}-0.6 \mathrm{Zr}$ alloys. As indicated, the as-extruded alloy exhibited finer grains compared to the as-cast alloy, accompanied by the average grain size decreased from about 81.2 to $24.0 \mu \mathrm{m}$ after extrusion. Uniform and equiaxed grains were observed in as-extruded alloy, indicating that a dynamic recrystallization process occurred. Some twins formed in both as-cast and as-extruded alloys because of the mechanical grinding during sample preparation. Further magnified SEM images are presented in Fig. 1c, d, more clearly showing that there was a notable difference in distribution and volume fraction of precipitate phases in two alloys. For the as-cast alloy, there were two kinds of precipitate phases: the coarse white particles within grain interiors and the fine white particles along grain boundaries. However, only few fine white particles are distributed randomly within grain interiors in the as-extruded alloy. Furthermore, some extremely fine particles in nanoscale were found in the as-extruded alloy. Based on calculation, the volume fraction of precipitate phases in $\mathrm{Mg}-2 \mathrm{Zn}-0.6 \mathrm{Zr}$ alloy decreased from $1.08 \%$ to $0.21 \%$ after extrusion. Table 2 shows the chemical composition of these white particles. The EDS analysis of the coarse particles gave the elemental composition of $\mathrm{Mg}_{7}$ $\mathrm{Zn}_{3}$, which was consistent with the discovery obtained by Hong et al. [2]. The fine particles in both alloys are rich in $\mathrm{Mg}, \mathrm{Zn}$ and $\mathrm{Zr}$. As for the extremely fine particles in asextruded alloy, Bhattacharjee et al. $[26,27]$ reported the similar precipitates with size about dozens to hundreds of nanometers, which were found in the ZK60 alloy after heat treatment or hot extrusion. Afterward, these precipitates were proved to be $\mathrm{Zr}$-rich $\mathrm{Mg}(\mathrm{Zn}, \mathrm{Zr})$ precipitates by TEM. Thus, in this study, it can be inferred that the $\mathrm{Mg}_{7} \mathrm{Zn}_{3}$ phase and fine particles (at grain boundaries) were almost dissolved into $\alpha-\mathrm{Mg}$ matrix during the heat treatment before extrusion, followed by a dynamic precipitation of $\mathrm{Mg}(\mathrm{Zn}, \mathrm{Zr})$ precipitates during the subsequent cooling or hot extrusion. However, all precipitate phases were not detected by XRD (Fig. 2), which should be attributed to their low volume fraction. Figure 3 presents the texture of the as-extruded $\mathrm{Mg}-2 \mathrm{Zn}-0.6 \mathrm{Zr}$ alloys in a form of inverse pole figure (corresponds to ED). Fiber texture was observed in the inverse pole figure, and the maximum intensity was centered at $\left[\begin{array}{ll}1 & 1-2\end{array}-\right.$ ], which was typical of extruded Mg alloys [28].

Volta potential maps were obtained by SKPFM to reveal the electrochemical potential differences between precipitate phases and $\alpha$-Mg matrix, as shown in Fig. 4. From the maps, the intermetallic particles have greater Volta potentials than the $\alpha-\mathrm{Mg}$ matrix for both as-cast and asextruded alloys, which reveals that the intermetallic particles are electrochemical nobler than $\alpha-\mathrm{Mg}$ matrix. Zhang et al. [25] and Baek et al. [29] also reached analogous findings about the nobler second phases. In general, the intermetallic particles act as micro-cathode, and matrix acts as micro-anode in the micro-galvanic corrosion. Nevertheless, considerable difference in Volta potential occurred depending on the types of the intermetallic particles. With regard to as-cast alloy, the Volta potential difference between $\mathrm{Mg}_{7} \mathrm{Zn}_{3}$ and $\alpha-\mathrm{Mg}$ matrix was about $120 \mathrm{mV}$, 

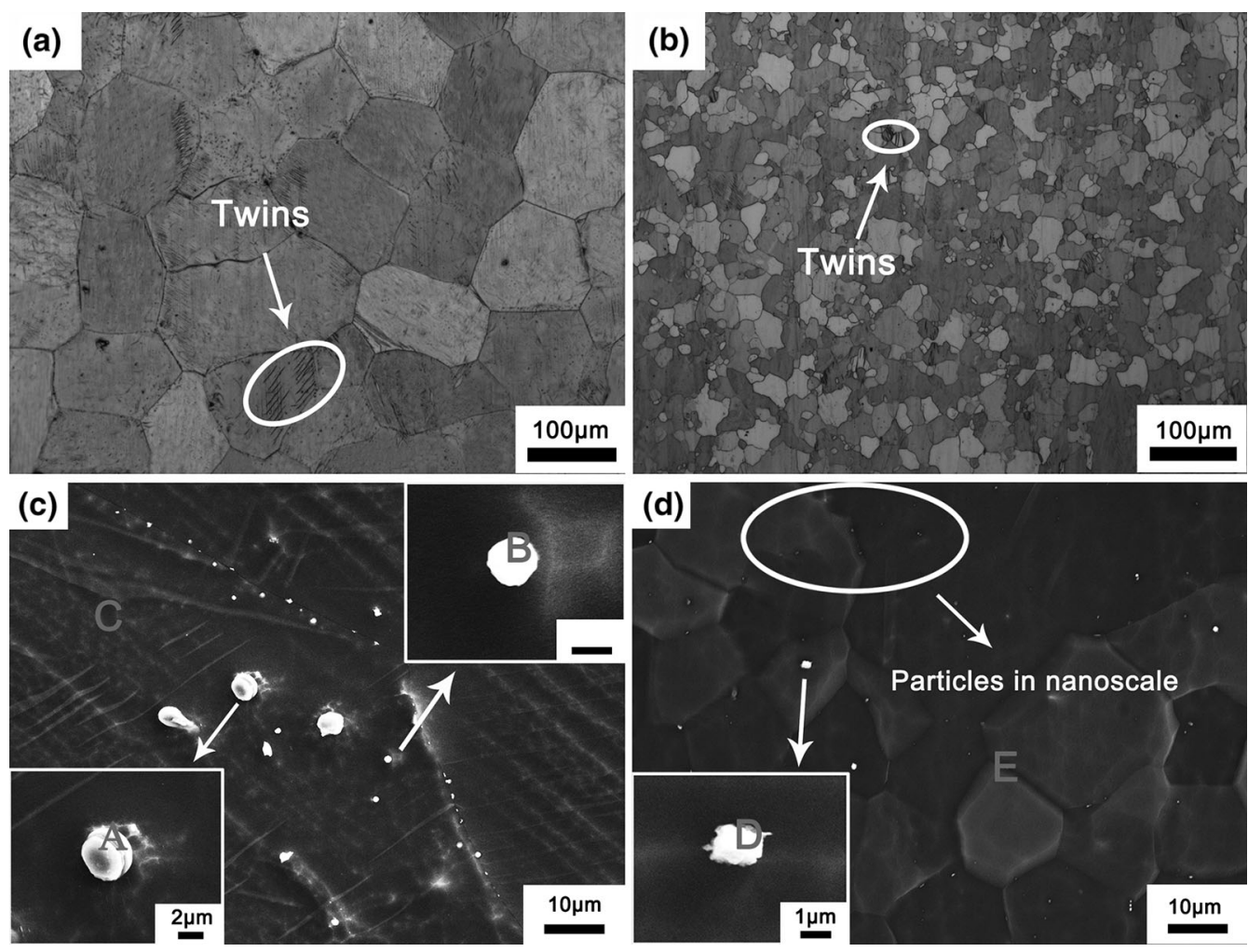

Fig. 1 Optical micrographs a, b and SEM images $\mathbf{c}, \mathbf{d}$ of $\mathrm{Mg}-2 \mathrm{Zn}-0.6 \mathrm{Zr}$ alloy: $\mathbf{a}, \mathbf{c}$ as-cast, $\mathbf{b}$, $\mathbf{d}$ as-extruded

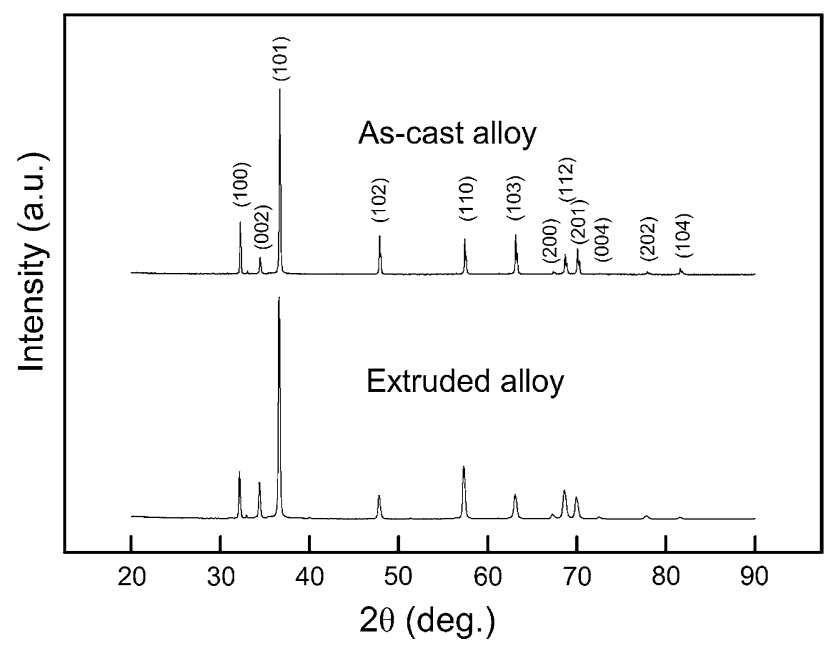

Fig. 2 XRD patterns of $\mathrm{Mg}-2 \mathrm{Zn}-0.6 \mathrm{Zr}$ alloy under different conditions

whereas the measuring result between $\mathrm{Mg}(\mathrm{Zn}, \mathrm{Zr})$ precipitates and matrix in as-extruded alloy was about $50 \mathrm{mV}$.

\subsection{Mechanical Properties}

Figure 5 shows the tensile stress-strain curves of $\mathrm{Mg}-2 \mathrm{Zn}$ $0.6 \mathrm{Zr}$ alloys at room temperature. The tensile strength, yield strength and elongation obtained from the curves are summarized in Fig. 6. As compared with pure $\mathrm{Mg}$ [2], the
Table 2 EDS analysis of tested alloys

\begin{tabular}{llrr}
\hline Element (at.\%) & Mg & \multicolumn{1}{c}{$\mathrm{Zn}$} & \multicolumn{1}{c}{$\mathrm{Zr}$} \\
\hline Area A & 65.87 & 34.07 & 0.06 \\
Area B & 58.46 & 18.16 & 23.38 \\
Area C & 99.36 & 0.53 & 0.11 \\
Area D & 56.94 & 12.40 & 30.66 \\
Area E & 99.23 & 0.68 & 0.09 \\
\hline
\end{tabular}

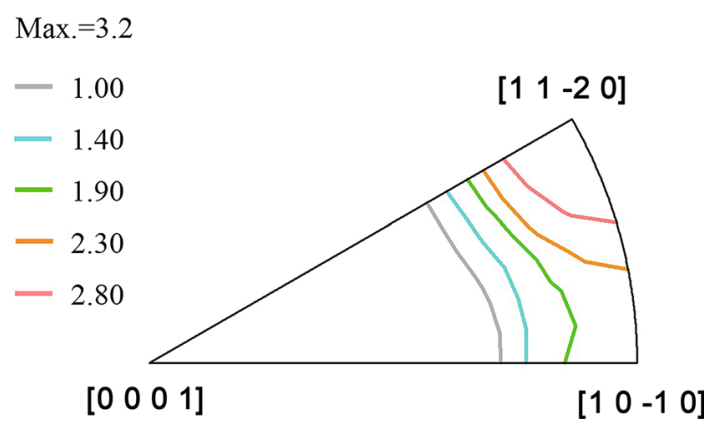

Fig. 3 Inverse pole figure of as-extruded $\mathrm{Mg}-2 \mathrm{Zn}-0.6 \mathrm{Zr}$ alloy

additions of $\mathrm{Zn}$ and $\mathrm{Zr}$ had a dramatic effect on rising tensile strength, yield strength and elongation. 

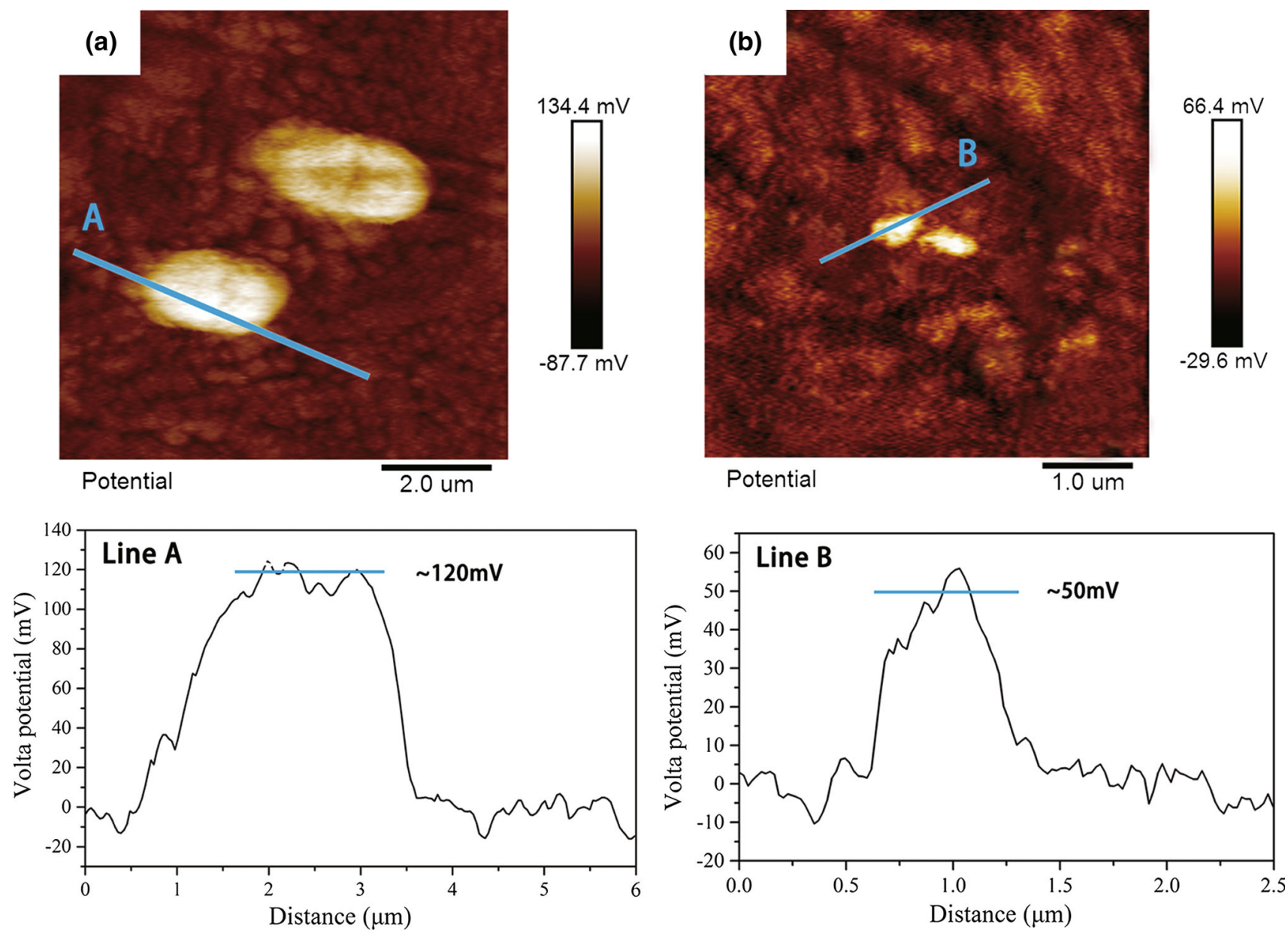

Fig. 4 SKPFM images of a as-cast alloy, $\mathbf{b}$ as-extruded alloy and corresponding Volta potential profiles along lines (A, B) in the SKPFM images

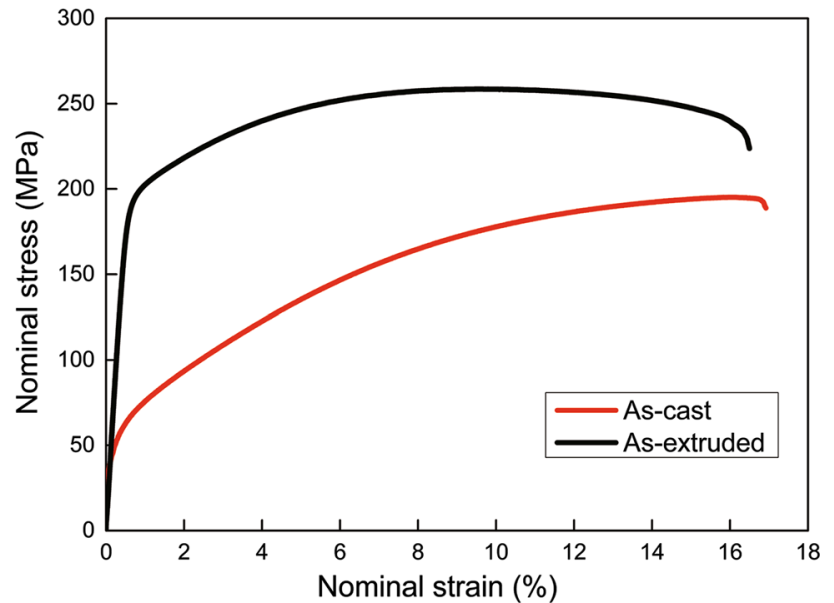

Fig. 5 Typical tensile stress-strain curves of $\mathrm{Mg}-2 \mathrm{Zn}-0.6 \mathrm{Zr}$ alloys at room temperature

From the overall perspective, as-extruded alloy exhibited better mechanical properties than as-cast alloy and showed excellent balance of strength and ductility. A tremendous reinforcement was achieved for yield strength

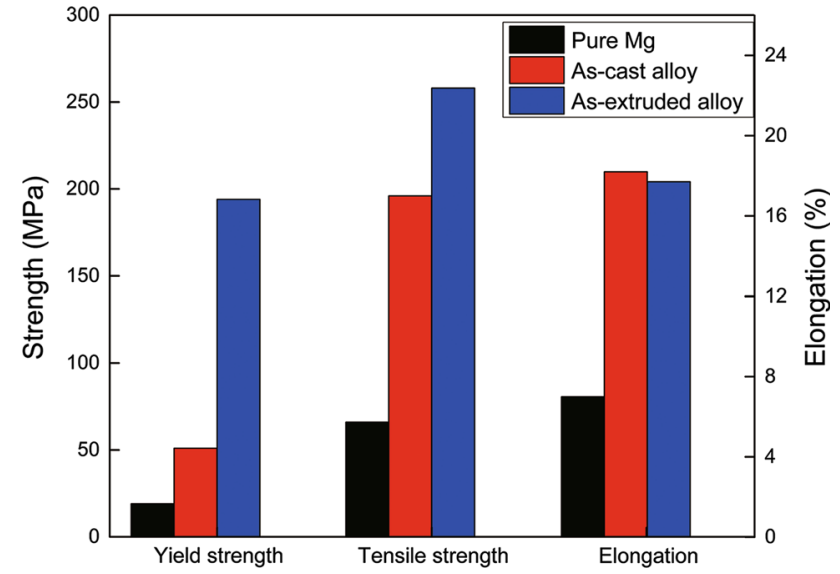

Fig. 6 Mechanical properties of pure $\mathrm{Mg}$ and $\mathrm{Mg}-2 \mathrm{Zn}-0.6 \mathrm{Zr}$ alloys

promoting from $51 \mathrm{MPa}$ to $194 \mathrm{MPa}$ by extrusion. As bone implant materials, high yield strength is desirable to prevent deformation under complex stress condition after implanting operation. So far as mechanical properties are concerned, as-extruded $\mathrm{Mg}-2 \mathrm{Zn}-0.6 \mathrm{Zr}$ alloy is an 
excellent substitute for natural bone among the materials presented in Fig. 6.

\subsection{Electrochemical Measurement}

Potentiodynamic polarization curves of $\mathrm{Mg}-2 \mathrm{Zn}-0.6 \mathrm{Zr}$ alloys in Hank's solution were obtained for evaluating their corrosion resistance, as depicted in Fig. 7. Overall, both alloys showed similar polarization behavior. Individually, the corrosion potential and corrosion current density of two alloys were distinct, in which the latter was considered as a significant reflection of corrosion resistance of materials. The corrosion current density of the as-extruded alloy was about $5.3 \mu \mathrm{A} / \mathrm{cm}^{2}$, lower than that of as-cast alloy $\left(12.2 \mu \mathrm{A} / \mathrm{cm}^{2}\right)$, which implies a superior corrosion resistance of as-extruded alloy in Hank's solution. Normally, anodic polarization curves represent the dissolution of $\mathrm{Mg}$, whereas cathodic polarization curves are assumed to indicate hydrogen evolution via water reduction [30]. In the anodic region, the current density of as-cast alloy at the same potential was greater than that of as-extruded alloy, manifesting the kinetic difficulty in anodic reaction for asextruded alloy. More important, the turning point in anodic region represented the breakup of corrosion film [31]. The breakdown potential $\left(E_{\mathrm{b}}\right)$ acquired from the turning point of as-extruded alloy $\left(-1.399 \mathrm{~V}_{\mathrm{SCE}}\right)$ was more positive than that of as-cast alloy $\left(-1.501 \mathrm{~V}_{\mathrm{SCE}}\right)$. From this perspective, the corrosion film formed on the surface of as-cast alloy was not as protective as that of as-extruded alloy for its susceptibility to break up. The parameters obtained from Tafel fitting are listed in Table 3 . The polarization resistance $\left(R_{\mathrm{p}}\right)$ was calculated according to the following equation [25]:

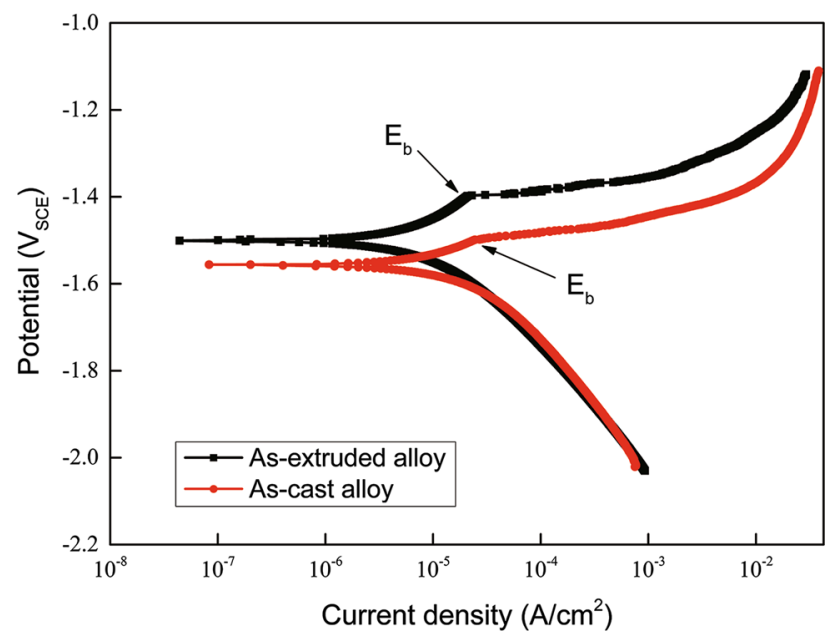

Fig. 7 Potentiodynamic polarization curves of $\mathrm{Mg}-2 \mathrm{Zn}-0.6 \mathrm{Zr}$ alloys immersed in Hank's solution
$R_{\mathrm{p}}=\frac{\beta_{\mathrm{a}} \beta_{\mathrm{c}}}{2.3\left(\beta_{\mathrm{a}}+\beta_{\mathrm{c}}\right) I_{\mathrm{coor}}}$

The polarization resistance was elevated to $6.30 \mathrm{k} \Omega \mathrm{cm}^{2}$ from $2.82 \mathrm{k} \Omega \mathrm{cm}^{2}$ for $\mathrm{Mg}-2 \mathrm{Zn}-0.6 \mathrm{Zr}$ alloy after extrusion. Previous study [32] pointed out that the change of polarization resistance corresponded to the corrosion behavior. Consequently, the tested alloy exhibited better corrosion resistance after extrusion.

Figure 8 presents the EIS spectra of as-cast and as-extruded alloys in Hank's solution. The Nyquist plot of both alloys consisted of a small capacitive loop at high frequency and a large well-defined capacitive loop at medium frequency. The diameter of the plot of as-extruded alloy was relatively large compared to that of as-cast alloy, suggesting the improved corrosion resistance of as-extruded alloy. In view of the Bode plot of impedance versus frequency, the impedance values always rose from high frequency to low frequency for two alloys. Note that the asextruded alloy had greater impedance value than as-cast alloy in low-frequency region. This phenomenon is believed to have relation with the formation of compact corrosion film in solution. In the case of Bode plot of degree versus frequency, two wave crests were observed for as-extruded alloy, implying the presence of two capacitance loops. The lack of second wave crest at high frequency in as-cast alloy may be related to its poor corrosion resistance, which remains to be studied. To further probe into the corrosion characteristics of the alloys, the spectra were fitted based on the equivalent circuits (Fig. 8d), and the fitting results are listed in Table 4. Thereinto, $R_{\mathrm{S}}$ represents the solution resistance. Constant phase element $\mathrm{CPE}_{\mathrm{dl}}$ is adopted in place of a capacitor to compensate for the non-homogeneity, which is characterized by $Y_{\mathrm{o}}$ and $n . R_{\mathrm{ct}}$ represents the charge transfer resistance at the interface between sample and tested solution. In general, $\mathrm{CPE}_{\mathrm{dl}}$ and $R_{\mathrm{ct}}$ are used to describe the capacitance loop in high frequency. The higher $R_{\mathrm{ct}}$ value indicates the lower dissolution rate of $\mathrm{Mg}$ substrate [31]. The $R_{\mathrm{f}}$ and $C_{\mathrm{f}}$ represent the film resistance and capacity, respectively. In this study, the values of $R_{\mathrm{ct}}$ and $R_{\mathrm{f}}$ increased after extrusion, which reveals the enhancement of corrosion resistance through extrusion. This phenomenon can be mainly attributed to the decrease of precipitate phases. This result corresponds well with the result of studies by $\mathrm{Wu}$ et al. [23], in which as-extruded AC22 alloy depicted the best corrosion resistance with the highest value of $R_{\text {ct }}$ and $R_{\mathrm{f}}$.

\subsection{Immersion Test}

The $\mathrm{pH}$ variation of Hank's solution was assessed for $\mathrm{Mg}-$ $2 \mathrm{Zn}-0.6 \mathrm{Zr}$ alloys at different time intervals up to $120 \mathrm{~h}$, as 
Table 3 Electrochemical parameters of $\mathrm{Mg}-2 \mathrm{Zn}-0.6 \mathrm{Zr}$ alloys in Hank's solution attained from the polarization test

\begin{tabular}{lllllll}
\hline Alloy & $E_{\text {corr }}\left(\mathrm{V}_{\mathrm{SCE}}\right)$ & $I_{\text {corr }}\left(\mu \mathrm{A} / \mathrm{cm}^{2}\right)$ & $E_{\mathrm{b}}\left(\mathrm{V}_{\mathrm{SCE}}\right)$ & $\beta_{\mathrm{c}}(\mathrm{mV} /$ decade $)$ & $\beta_{\mathrm{a}}(\mathrm{mV} / \mathrm{decade})$ & $R_{\mathrm{p}}\left(\mathrm{k} \Omega \mathrm{cm}^{2}\right)$ \\
\hline As-cast & -1.550 & 12.2 & -1.501 & 178.1 & 142.2 & 2.82 \\
As-extruded & -1.498 & 5.3 & -1.399 & 146.8 & 161.2 & 6.30 \\
\hline
\end{tabular}
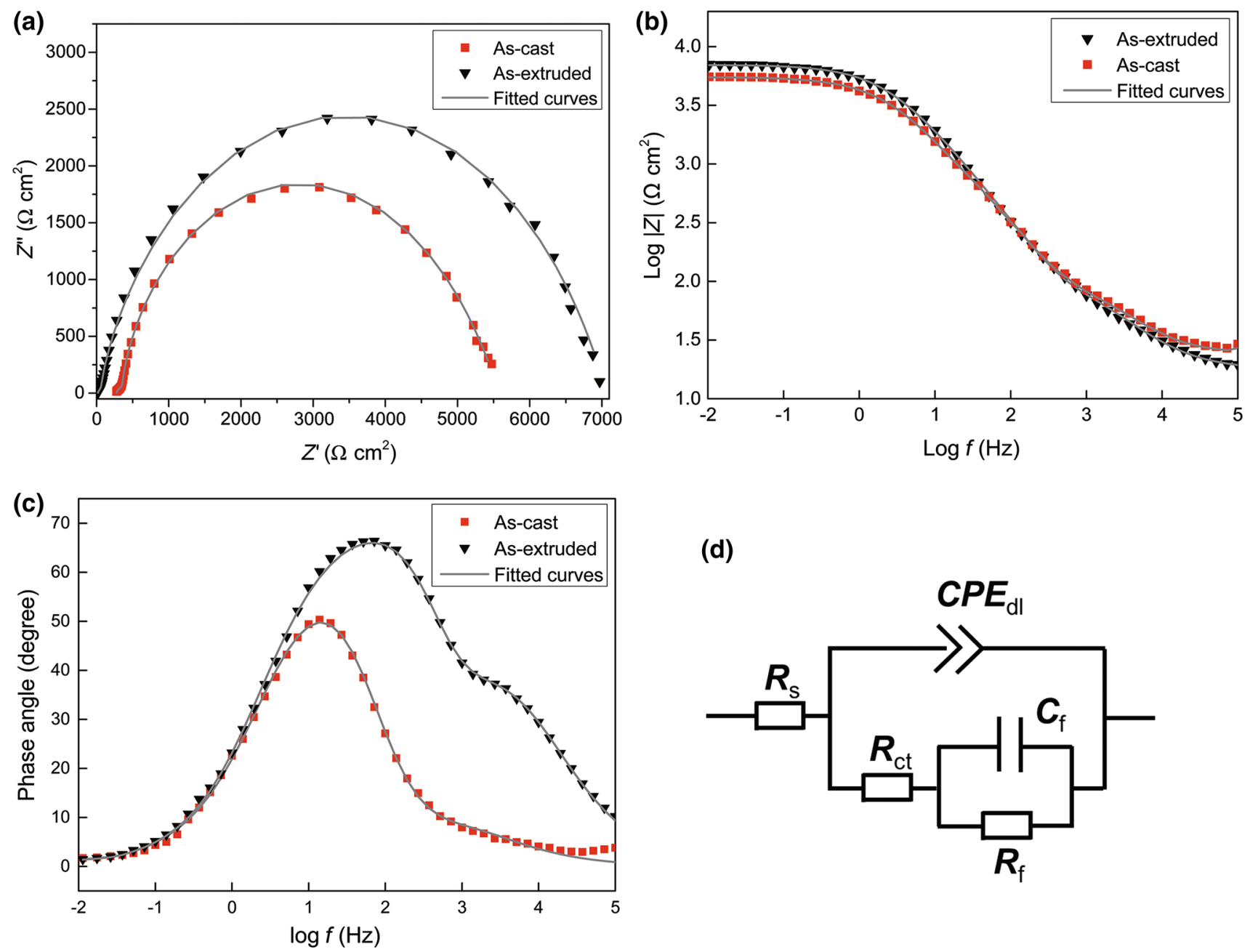

Fig. 8 EIS plots of Mg-2Zn-0.6Zr alloys in Hank's solution: a Nyquist plot, b Bode plot of $|\mathrm{Z}|$ versus frequency, $\mathbf{c}$ Bode plot of degree versus frequency, d equivalent circuit

Table 4 Fitting results of the EIS spectra

\begin{tabular}{lllllll}
\hline Alloy & $R_{\mathrm{s}}\left(\Omega \mathrm{cm}^{2}\right)$ & $Y_{\mathrm{o}}\left(\mu \Omega^{-1} \mathrm{~cm}^{-2} \mathrm{~s}^{-1}\right)$ & $n$ & $R_{\mathrm{ct}}\left(\Omega \mathrm{cm}^{2}\right)$ & $C_{\mathrm{f}}\left(\mu \mathrm{F} \mathrm{cm} \mathrm{cm}^{-2}\right)$ & $R_{\mathrm{f}}\left(\Omega \mathrm{cm}^{2}\right)$ \\
\hline As-cast & 27.8 & 23.3 & 0.678 & 5139.2 & 4.6 & 144.2 \\
As-extruded & 17.6 & 18.0 & 0.724 & 6904.7 & 1.9 & 164.4 \\
\hline
\end{tabular}

shown in Fig. 9. It can be seen that $\mathrm{pH}$ variation corresponding to two alloys exhibited a similar trend: a sharp rise in the initial $24 \mathrm{~h}$, followed by a moderate increase, and tended to saturation at last. The change in $\mathrm{pH}$ value can be ascribed to the generation of $\mathrm{OH}^{-}$anions, which was accompanied with the release of hydrogen at the same time. Generally, a lower $\mathrm{pH}$ stands for a higher corrosion resistance for immersed sample. The lower $\mathrm{pH}$ value of asextruded alloy in comparison with as-cast alloy demonstrated the superior corrosion resistance of the former. 


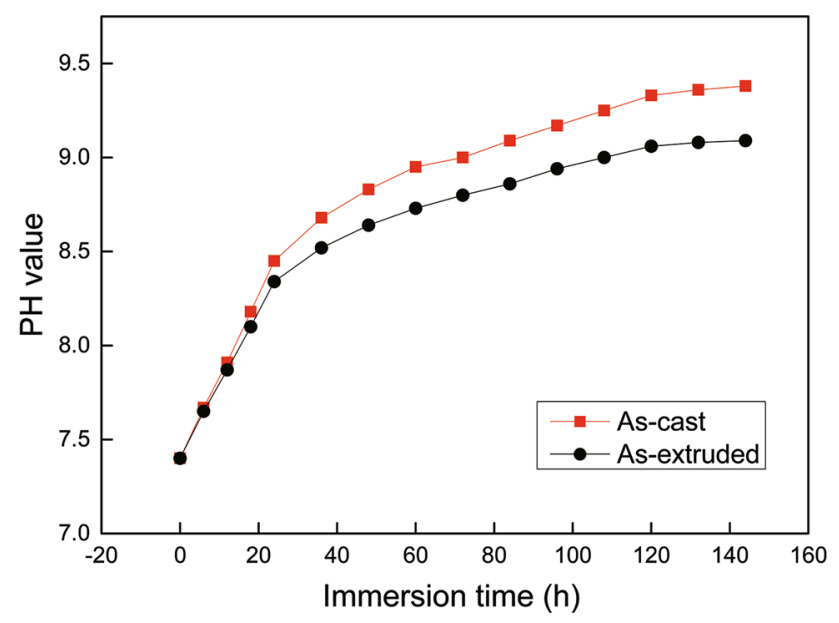

Fig. $9 \mathrm{pH}$ variation of Hank's solution for $\mathrm{Mg}-2 \mathrm{Zn}-0.6 \mathrm{Zr}$ alloys

Figure 10 shows the three-dimensional (3D) morphologies of tested alloys after removal of corrosion products, where the corrosion pits and cross-section shape were observed using laser scanning confocal microscopy (LSCM). Notable corrosion pits with large size were found in as-cast alloy, indicating a localized corrosion appearance. Cai et al. [11] also found the similar corrosion morphologies and attributed them to the localized corrosion attack. Previous studies have pointed out that the formation of deep pits has a deleterious effect on the overall corrosion resistance [33]. But for as-extruded alloy, it showed a relatively flat and uniform corrosion appearance, revealing the slighter corrosion attack attributed by decreased precipitate phases. Scattered tiny pits were observed distributing on the surface, as a result of microgalvanic corrosion between magnesium matrix and fine $\mathrm{Mg}(\mathrm{Zn}, \mathrm{Zr})$ precipitates in Hank's solution. After immersion for 10 days, the corrosion rates of both alloys were calculated from the weight loss. The as-extruded alloy exhibited the corrosion rate of $0.32 \mathrm{~mm} / \mathrm{year}$, nearly onefifth of the corrosion rate of as-cast alloy ( $1.68 \mathrm{~mm} / \mathrm{year})$. The huge gap in corrosion rate intuitively reflected the enhancement of corrosion resistance of $\mathrm{Mg}-2 \mathrm{Zn}-0.6 \mathrm{Zr}$ alloy by extrusion.

To apperceive the interior of the corrosion films, the cross-sectional morphologies of the samples after a 10-day immersion were investigated, as shown in Fig. 11. For the as-cast alloy, the corrosion attacks went deep into the magnesium matrix. In contrast, the corrosion of as-extruded alloy was almost concentrated on the matrix surface. The zigzag interface between uncorroded matrix and corrosion products appeared in as-cast alloy, accompanied by deeper localized corrosion area. That interface indicated the severe corrosion attacks suffered for the as-cast alloy, while the as-extruded alloy underwent relatively uniform and slight corrosion. The average thickness of the corrosion film formed in as-cast alloy was approximately $40 \mu \mathrm{m}$, far greater than that in as-extruded alloy (about $10 \mu \mathrm{m}$ ). The results corresponded to the corrosion degree of two alloys.

Figure 12 shows the corrosion morphologies of samples in Hank's solution for different periods of time. After immersion for $0.5 \mathrm{~h}$, the surface of alloys lost its gloss and got dark and was covered with some punctate white products. This phenomenon declared the beginning of corrosion attack. As immersion time prolonged to $12 \mathrm{~h}$, some cracks were visible and the punctate corrosion products increased in quantities and sizes. In the case of ascast alloy, there exists localized corrosion attack, characterized by concentrated cracks and raised surface, which was also found in other Mg alloys [21]. With the immersion time extended to 5 days, the white corrosion products on the surface increased for both alloys. A large area of corrosion film broke up in as-cast alloy, together with the formation of broad and dense cracks, tremendously destroying the integrity of the corrosion film. Thus, more electrolyte solution was able to permeate into corrosion film and contact with the subjacent magnesium matrix for continuous corrosion attack. In comparison, the corrosion film of as-extruded alloy was relatively compact and complete and provided the effective protection for the matrix.

The corrosion products formed on the surface of $\mathrm{Mg}_{-}$ $2 \mathrm{Zn}-0.6 \mathrm{Zr}$ alloys were analyzed by XRD (Fig. 13). It can be seen from XRD patterns, $\mathrm{Mg}(\mathrm{OH})_{2}$, hydroxyapatite $\left(\mathrm{Ca}_{10}\left(\mathrm{PO}_{4}\right)_{6}(\mathrm{OH})_{2}, \mathrm{HA}\right)$ and $(\mathrm{Ca}, \mathrm{Mg})_{3}\left(\mathrm{PO}_{4}\right)_{2}$ were the dominant degradation products formed during immersion test. Moreover, the peak intensities of corrosion products in as-extruded alloy spectra were much lower than those in as-cast alloy, disclosing a lower dissolution rate of as-extruded alloy. Considering that $\mathrm{Mg}(\mathrm{OH})_{2}$ existed as a layer deposited on the surface of samples, the punctate white products were most likely to be phosphates [including HA and $\left.(\mathrm{Ca}, \mathrm{Mg})_{3}\left(\mathrm{PO}_{4}\right)_{2}\right]$.

\section{Discussion}

\subsection{Effect of Microstructure Evolution on Strength/Corrosion}

The comprehensive performance of various alloys $[2,11,34-38]$ is compared in Fig. 14, from which as-extruded $\mathrm{Mg}-2 \mathrm{Zn}-0.6 \mathrm{Zr}$ exhibited the relatively outstanding performance and was promising to develop as a biodegradable implant material. Thereinto, live/dead cell viability assay and indirect MTT assay were performed in as-cast ZK40 alloy [2], and the results showed favorable cell viability and minimal cytotoxicity. Hence, it can be inferred that as-extruded $\mathrm{Mg}-2 \mathrm{Zn}-0.6 \mathrm{Zr}$ may also possess 

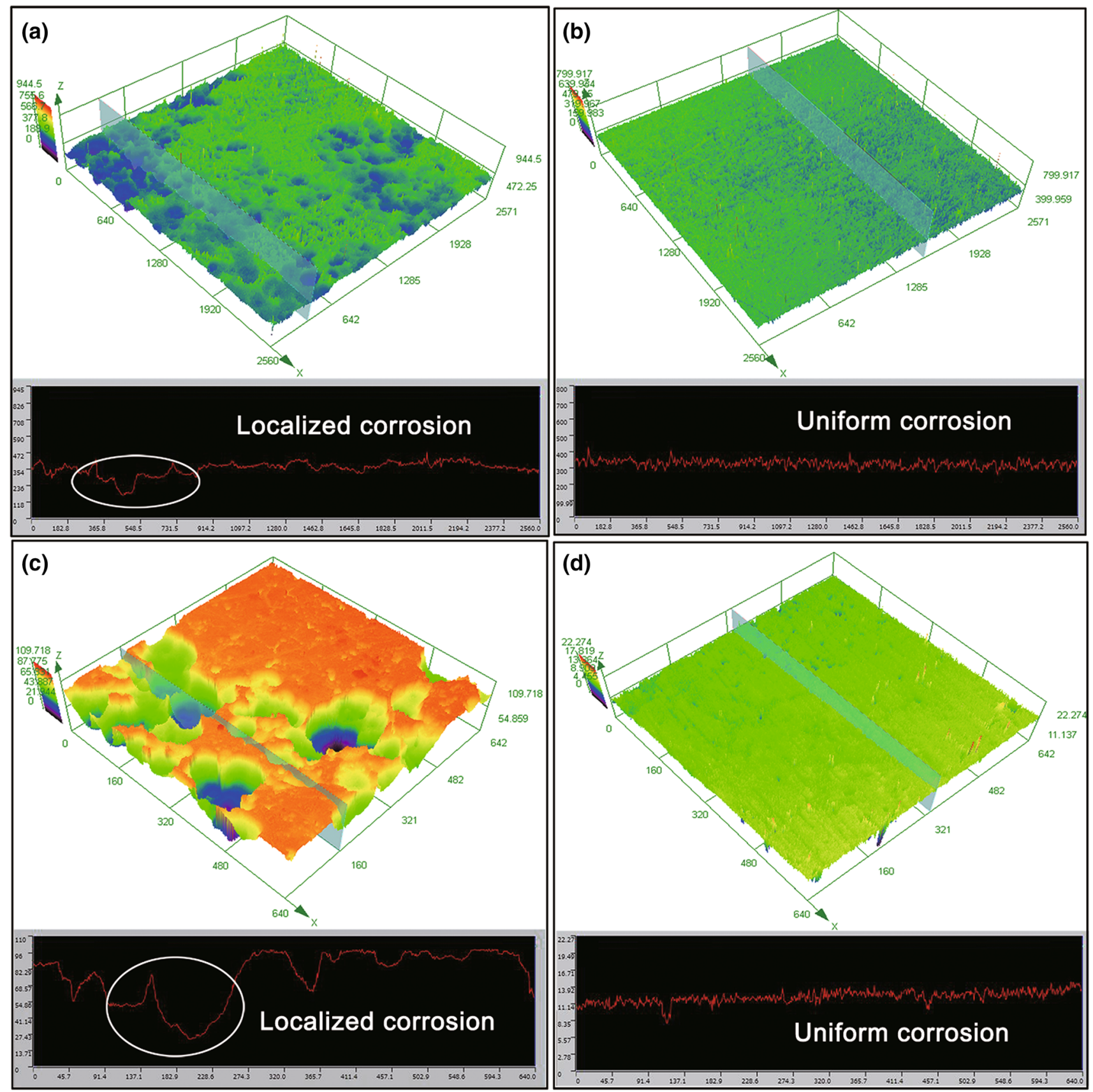

Fig. 10 Three-dimensional morphologies of tested alloys after removal of corrosion products: $\mathbf{a}, \mathbf{c}$ as-cast alloy, $\mathbf{b}, \mathbf{d}$ as-extruded alloy

favorable cytocompatibility due to its similar composition with ZK40 alloy.

The enhanced properties were attributed to microstructure evolution during extrusion to a large extent. Thereinto, the superior performance in strength of as-extruded alloy was mainly ascribed to refined grains, dispersive precipitate phases and texture. The decrease of grain size after extrusion led to the strength improvement according to the Hall-Petch relationship $\left(\sigma_{\mathrm{s}}=\sigma_{0}+K d^{-1 / 2}\right)$. The increasing grain boundaries by grain refinement caused strong obstacles inhibiting the mobility of dislocation in the initial stage of plastic deformation, so as to markedly promote the yield strength. The precipitation strengthening depended on the size, distribution, morphology and the density of precipitates [36]. Many previous studies confirmed the formation of texture after hot extrusion [21, 24]. For metals in which the slip systems are limited to some extent, such as $\mathrm{Mg}$, texture can contribute to strength [39, 40]. Texture strengthening is caused by deformation which limits the activity of basal slip when tensile behavior happens [41]. 

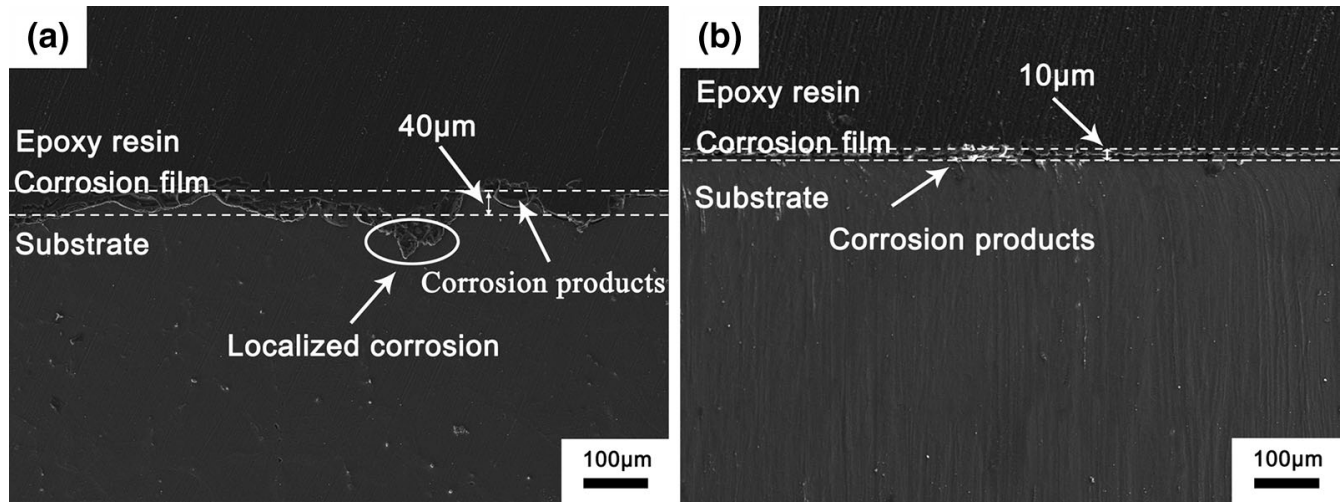

Fig. 11 SEM images of the cross-sectional morphologies after immersion in Hank's solution for 10 days: a as-cast alloy, $\mathbf{b}$ as-extruded alloy
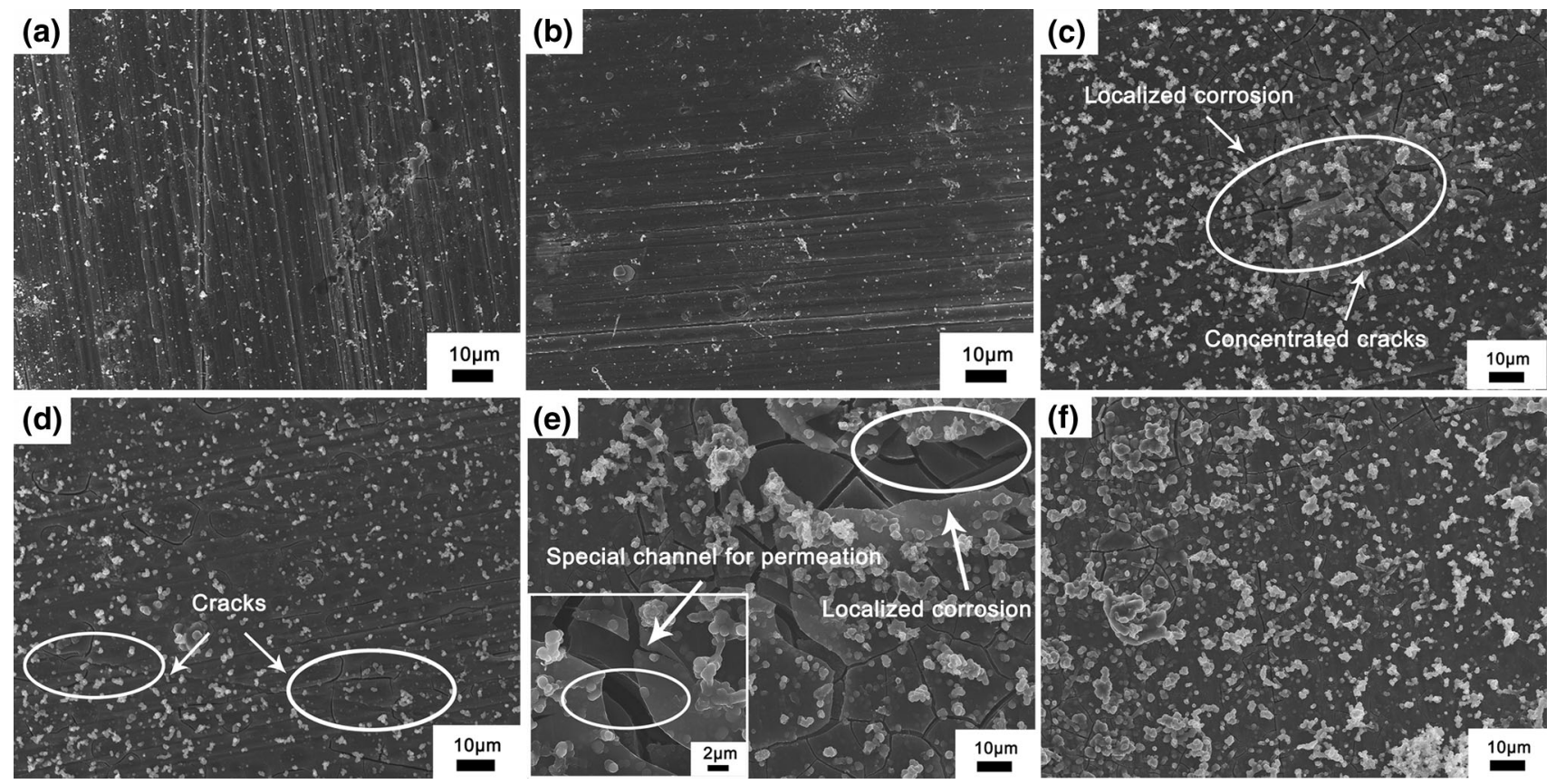

Fig. 12 Corrosion morphologies of as-cast $\mathbf{a}, \mathbf{c}, \mathbf{e}$ and as-extruded $\mathbf{b}, \mathbf{d}, \mathbf{f} \mathrm{Mg}-2 \mathrm{Zn}-0.6 \mathrm{Zr}$ alloys after immersion in Hank's solution for $\mathbf{a}, \mathbf{b}$ $0.5 \mathrm{~h}$, c, d $12 \mathrm{~h}, \mathbf{e}, \mathbf{f} 5 \mathrm{~d}$

Plenty of investigations revealed that the microstructure comprising precipitate phases and grain size played a pronounced role in affecting the corrosion behavior of magnesium alloy [42, 43]. The influence of precipitate phases on corrosion mainly depended on their category, volume fraction and size. For $\mathrm{Mg}-2 \mathrm{Zn}-0.6 \mathrm{Zr}$ alloy, the precipitate phases decreased in both volume fraction and size (Fig. 1) after extrusion, and the SKPFM images (Fig. 4) indicated a reduction in Volta potential difference between precipitate phases and magnesium matrix by extrusion. Previous study [44] found that the Volta potential difference and areas ratio between anodic and cathodic areas were predominant factors, which determined the galvanic corrosion rate of magnesium alloys. As a result, more micro-galvanic couples and faster corrosion rate were achieved in as-cast alloy, leading to a higher degree of micro-galvanic corrosion than as-extruded alloy. Wu et al. [23] also investigated the semi-continuous channels formed by micro-galvanic couples and confirmed the deterioration effect of micro-galvanic corrosion on matrix. Furthermore, the evolution of precipitate phases can better explicate the surface morphologies of corroded alloys, as shown in Fig. 10. The dissolution of magnesium matrix adjacent to precipitate phases occurred preferentially. When it comes to as-cast alloy, quantities of large and deep corrosion pits formed and propagated horizontally, resulting in large area of interconnected corrosion pits ultimately. In some areas, the existence of unevenly distributed and agglomerated coarse particles caused the localized corrosion. However, for as-extruded alloy, there only formed some small and 


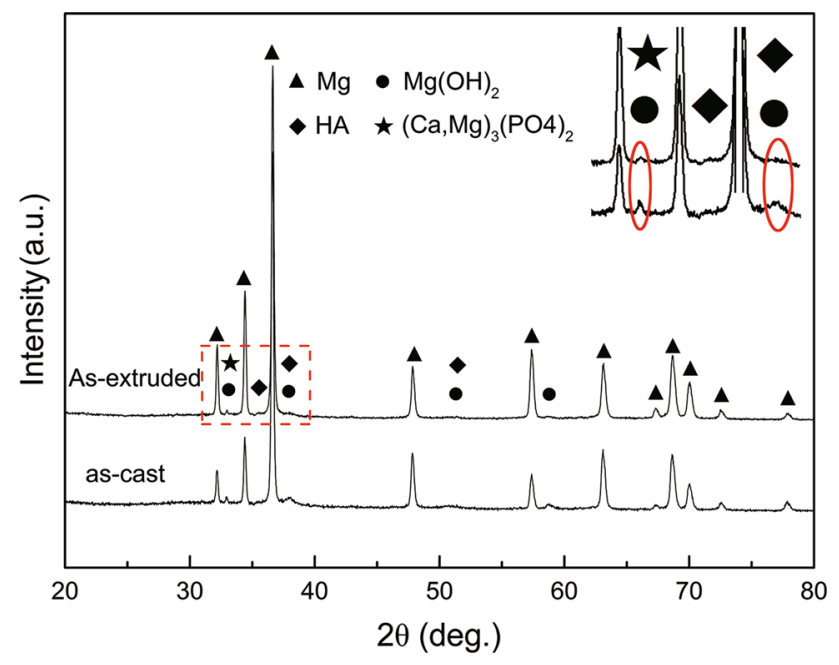

Fig. $13 \mathrm{XRD}$ analysis of the corrosion products formed on the surface of $\mathrm{Mg}-2 \mathrm{Zn}-0.6 \mathrm{Zr}$ alloys

discrete tiny pits engendered by micro-galvanic corrosion owing to the precipitate phases with decreased volume fraction, size and relatively small potential difference between intermetallic particles and $\alpha-\mathrm{Mg}$ matrix. In addition, it is widely believed that the reduction of grain size brought about the improved corrosion resistance. Liao et al. [45] reached a formula that the corrosion rate of magnesium alloy has a linear relationship with reciprocal square root of average grain size $\left(\mathrm{d}^{-1 / 2}\right)$. Namely, the corrosion resistance tended to increase with the reduction of grain size. And the reason was attributed to the enhanced passivity by helping to relieve the stress on surface film through refinement [46]. In the present study, the significant decrease in grain size by extrusion was observed, and this might lead to the slighter corrosion in all probability.

\subsection{Effect of Corrosion Film on Corrosion}

The protectiveness of corrosion film formed on the alloy surface was another key factor in determining the corrosion resistance. The corrosion film with different immersion times was compared to apperceive its formation process (Fig. 12). Both alloys showed the analogous trend: With the prolongation of immersion time, more corrosion products got deposited, and more cracks appeared on the surface of corrosion film. The concentrated and wide cracks formed in as-cast alloy severely damaged the protectiveness of corrosion film, thus providing special channel for corrosive ions to contact with fresh matrix. Hence, the matrix subjacent to the corrosion film would keep suffering from corrosion. However, the as-extruded alloy formed more protective corrosion film for its inconspicuous and small cracks. The diameter of the loop for as-extruded alloy was much larger than that for as-cast alloy, which also implied the considerable protection of corrosion film for as-extruded alloy (Fig. 8). The initiation of cracks might be because that the stress within corrosion film reached a limit. The turning point appearing in the potentiodynamic polarization curves demonstrated the breakup of the corrosion film (Fig. 7). Besides, the hydrogen bubbles produced on the naked surface contributed to the breakup of corrosion film as well. With respect to as-cast alloy, more electrolyte solution permeated from dense cracks and reacted with fresh magnesium matrix, thus

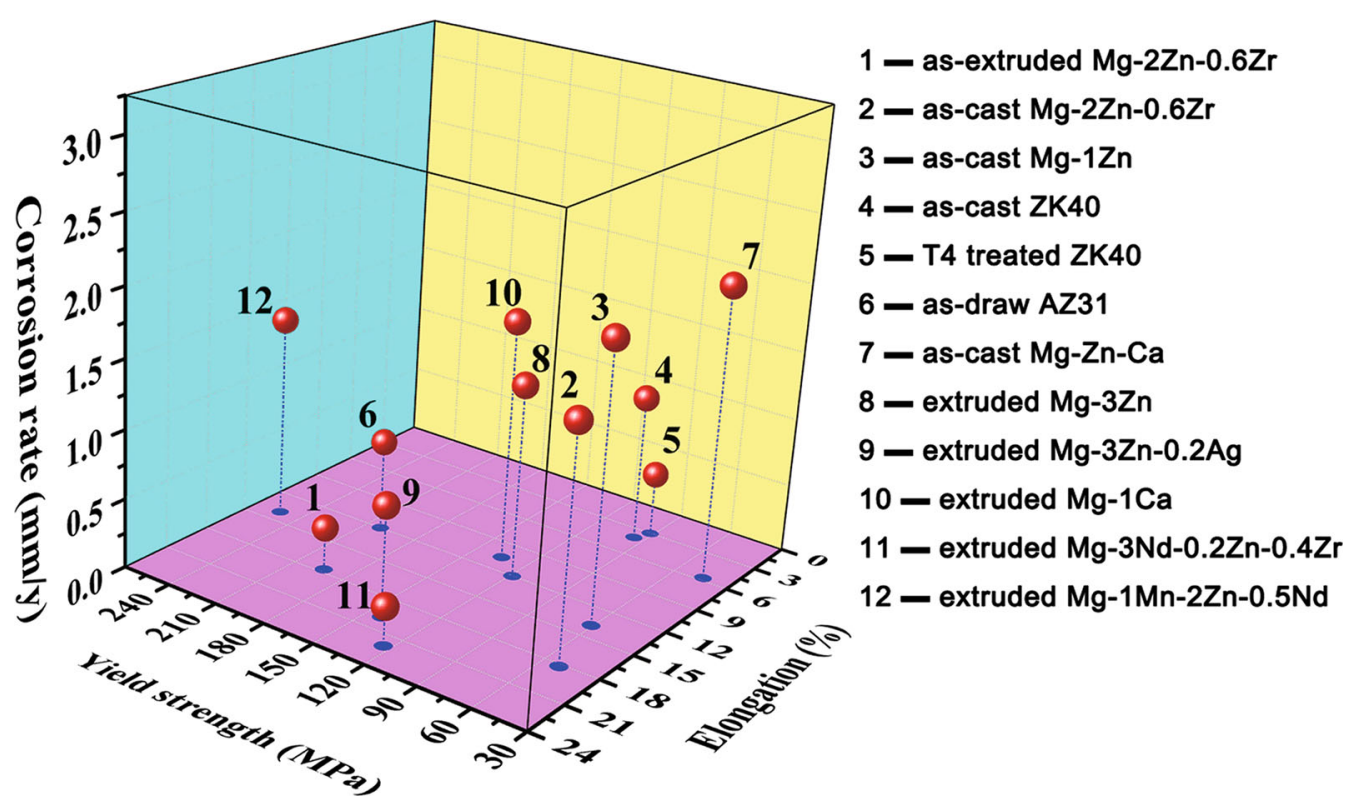

Fig. 14 Statistics of material properties of biodegradable magnesium alloys 
releasing more bubbles. And the bubbles would enlarge the cracks conversely, leading to allowance of more solution permeation. Over time, the corrosion degree was significantly deepened.

\subsection{Corrosion Mechanism}

In terms of degradation, the dissolution of matrix, the formation and rupture of corrosion film, the accelerated effect of micro-galvanic couples and the limited protectiveness of corrosion film are the primary coverage in the overall corrosion process. To begin with, when the substrate exposed to corrosive solution in the initial stage, quantities of micro-galvanic couples formed and the matrix adjacent to precipitate phases dissolved preferentially. Along with the attack of $\mathrm{Cl}^{-}$, hydrogen bubbles and $\mathrm{OH}^{-}$ released from cathode, as have been testified by the increase of $\mathrm{pH}$ value (Fig. 9). The rise of $\mathrm{Mg}^{2+}$ and $\mathrm{OH}^{-}$ ions concentration led to the formation of insoluble $\mathrm{Mg}(\mathrm{OH})_{2}$ on the substrate surface, which was in accordance with Eqs. (2)-(4).

Anodic reaction: $\mathrm{Mg} \rightarrow \mathrm{Mg}^{2+}+2 e^{-}$,

Cathodic reaction: $\quad 2 \mathrm{H}_{2} \mathrm{O}+2 e^{-} \rightarrow \mathrm{H}_{2} \uparrow+2 \mathrm{OH}^{-}$,

The total reaction: $\mathrm{Mg}+2 \mathrm{H}_{2} \mathrm{O} \rightarrow \mathrm{Mg}(\mathrm{OH})_{2} \downarrow+\mathrm{H}_{2} \uparrow$,

With immersion time prolonged, the $\mathrm{Mg}(\mathrm{OH})_{2}$ deposited on the surface gradually accumulated. The corrosion film of as-cast alloy was thicker than that of as-extruded alloy owing to more remarkable micro-galvanic corrosion. After the enrichment of $\mathrm{OH}^{-}$in solution, the $\mathrm{OH}^{-}$reacted with $\mathrm{HPO}_{4}{ }^{-}$and $\mathrm{HPO}_{4}{ }^{2-}$, producing $\mathrm{PO}_{4}{ }^{3-}$ by the following reactions [47]:

$$
\begin{aligned}
& \mathrm{H}_{2} \mathrm{PO}_{4}^{-}+2 \mathrm{OH}^{-} \rightarrow \mathrm{PO}_{4}^{3-}+2 \mathrm{H}_{2} \mathrm{O}, \\
& 2 \mathrm{HPO}_{4}^{2-}+2 \mathrm{OH}^{-} \rightarrow 2 \mathrm{PO}_{4}^{3-}+2 \mathrm{H}_{2} \mathrm{O},
\end{aligned}
$$

The $\mathrm{PO}_{4}{ }^{3-}$ was able to combine with $\mathrm{Mg}^{2+}$ and $\mathrm{Ca}^{2+}$ in electrolyte solution and produced the phosphates comprising $\mathrm{Ca}_{10}\left(\mathrm{PO}_{4}\right)_{6}(\mathrm{OH})_{2}(\mathrm{HA})$ and $(\mathrm{Ca}, \mathrm{Mg})_{3}\left(\mathrm{PO}_{4}\right)_{2}$ [48]. The phosphates preferentially nucleated and grow on defects of corrosion film, depositing as the punctate white products. Due to the stress within corrosion film and the impact action of hydrogen bubbles, tiny cracks appeared and served as the special channel for ions permeation. Therefore, the bare matrix could continue to be corroded. For as-extruded alloy, only some tiny pits formed (Fig. 10b, d) around the fine intermetallic particles under the effect of weaker galvanic corrosion. When it comes to as-cast alloy, the corrosion pits propagated along lateral and longitudinal direction, leading to the large area of corrosion region with pretty depth (Fig. 10a, c). The localized corrosion violently destroyed the completeness of corrosion film (Fig. 12c, e) and promoted the permeation of solution, thus accelerating the corrosion proceeding and enlarging the corrosion area.

\section{Conclusions}

1. $\mathrm{Mg}_{7} \mathrm{Zn}_{3}$ phase and other intermetallic particles almost dissolved into $\alpha-\mathrm{Mg}$ matrix due to solution treatment, followed by a dynamic precipitation of $\mathrm{Mg}(\mathrm{Zn}, \mathrm{Zr})$ precipitates. After extrusion, the average grain size significantly decreased from about 81.2 to $24.0 \mu \mathrm{m}$, and notable reductions were observed in the volume fraction and size of precipitate phases.

2. As-extruded alloy exhibited better mechanical performance than as-cast alloy, especially in yield strength which was promoted from 51 to $194 \mathrm{MPa}$. The superior performance in strength was ascribed to refined grains, dispersive precipitate phases and texture.

3. The electrochemical measurement and immersion test indicated the enhanced corrosion resistance of $\mathrm{Mg}$ $2 \mathrm{Zn}-0.6 \mathrm{Zr}$ alloy by extrusion, with corrosion morphology transformed from severe localized corrosion into uniform corrosion. The decreased volume fraction and Volta potential of precipitate phases, the refinement of grain size, as well as the formation of more protective corrosion film were considered as key reasons for the enhanced corrosion resistance.

Acknowledgements This work was supported by the National Key Research and Development Program of China (Grant No. 2016YFB0700300).

\section{References}

[1] M.P. Staiger, A.M. Pietak, J. Huadmai, G. Dias, Biomaterials 27, 1728 (2006)

[2] D. Hong, P. Saha, D. Chou, B. Lee, B.E. Collins, Z. Tan, Z. Dong, P.N. Kumta, Acta Biomater. 9, 8534 (2013)

[3] Y.F. Zheng, X.N. Gu, F. Witte, Mater. Sci. Eng. R 77, 1 (2014)

[4] P.C. Wong, P.H. Tsai, T.H. Li, C.K. Cheng, J. Jang, J. Huang, J. Alloys Compd. 699, 914 (2017)

[5] A. Hartwig, Mutat. Res. 475, 113 (2001)

[6] M. Alvarez-Lopez, M.D. Pereda, J.A. Del Valle, M. FernandezLorenzo, M.C. Garcia-Alonso, O.A. Ruano, M.L. Escudero, Acta Biomater. 6, 1763 (2010)

[7] D. Vojtěch, H. Č́ížová, K. Volenec, Kovove Mater. 44, 211 (2006)

[8] S. El-Rahman, Pharmacol. Res. 47, 189 (2003)

[9] N. Hort, Y. Huang, D. Fechner, M. Störmer, C. Blawert, F. Witte, C. Vogt, H. Drücker, R. Willumeit, K.U. Kainer, Acta Biomater. 6, 1714 (2010)

[10] G. Song, Corros. Sci. 49, 1696 (2007)

[11] S. Cai, T. Lei, N. Li, F. Feng, Mater. Sci. Eng. C 32, 2570 (2012) 
[12] S. Zhang, X. Zhang, C. Zhao, J. Li, Y. Song, C. Xie, H. Tao, Y. Zhang, Y. He, Y. Jiang, Acta Biomater. 6, 626 (2010)

[13] H. Jia, X. Feng, Y. Yang, Corros. Sci. 120, 75 (2017)

[14] H. Li, Q. Peng, X. Li, K. Li, Z. Han, D. Fang, Mater. Des. 58, 43 (2014)

[15] A. Prasad, P.J. Uggowitzer, Z. Shi, A. Atrens, Adv. Eng. Mater. 14, 477 (2012)

[16] X. Ye, M. Chen, M. Yang, J. Wei, D. Liu, J. Mater. Sci. Mater. Med. 21, 1321 (2010)

[17] H. Jiang, J. Wang, M. Chen, D. Liu, Mater. Sci. Eng. C 75, 1068 (2017)

[18] H. Jia, X. Feng, Y. Yang, J. Magnes. Alloy 3, 247 (2015)

[19] Y. Song, D. Shan, R. Chen, E. Han, Corros. Sci. 52, 1830 (2010)

[20] C. Shuai, Y. Yang, P. Wu, X. Lin, Y. Liu, Y. Zhou, P. Feng, X. Liu, S. Peng, J. Alloys Compd. 691, 961 (2017)

[21] Y.S. Jeong, W.J. Kim, Corros. Sci. 82, 392 (2014)

[22] C. Zhao, F. Pan, L. Zhang, H. Pan, K. Song, A. Tang, Mater. Sci. Eng. C 70, 1081 (2017)

[23] P. Wu, F. Xu, K. Deng, F. Han, Z. Zhang, R. Gao, Corros. Sci. 127, 280 (2017)

[24] Y. Bai, W. Cheng, S. Ma, J. Zhang, C. Guo, Y. Zhang, Acta Metall. Sin. (Engl. Lett.) 31, 487 (2018)

[25] Y. Zhang, J. Li, J. Li, J. Alloys Compd. 728, 37 (2017)

[26] C.L. Bhattacharjee, T.T. Mendis, T. Sasaki, K. Ohkubo, Hono. Scripta Mater. 67, 967 (2012)

[27] T. Bhattacharjee, T. Nakata, T.T. Sasaki, S. Kamado, K. Hono, Scripta Mater. 90, 37 (2014)

[28] Y.N. Wang, J.C. Huang, Mater. Chem. Phys. 81, 11 (2003)

[29] S. Baek, H.J. Kim, H.Y. Jeong, S. Sohn, H. Shin, K. Choi, K. Lee, J.G. Lee, C.D. Yim, B.S. You, H. Ha, S.S. Park, Corros. Sci. 112, 44 (2016)

[30] Y. Choi, S. Salman, K. Kuroda, M. Okido, Corros. Sci. 63, 5 (2012)
[31] Y. Song, D. Shan, E. Han, J. Mater. Sci. Technol. 33, 954 (2017)

[32] H.R. Bakhsheshi-Rad, M.R. Abdul-Kadir, M.H. Idris, S. Farahany, Corros. Sci. 64, 184 (2012)

[33] R. Hahn, J.G. Brunner, J. Kunze, P. Schmuki, S. Virtanen, Electrochem. Commun. 10, 288 (2008)

[34] B. Zhang, Y. Hou, X. Wang, Y. Wang, L. Geng, Mater. Sci. Eng. C 31, 1667 (2011)

[35] H. Zhao, L. Wang, Y. Ren, B. Yang, S. Li, G. Qin, Acta Metall. Sin. (Engl. Lett.) 31, 575 (2018)

[36] Z. Li, X. Gu, S. Lou, Y. Zheng, Biomaterials 29, 1329 (2008)

[37] X. Zhang, G. Yuan, L. Mao, J. Niu, P. Fu, W. Ding, J. Mech. Behav. Biomed. 7, 77 (2012)

[38] Y. Zhou, Y. Li, D. Luo, Y. Ding, P. Hodgson, Mater. Sci. Eng. C 49, 93 (2015)

[39] D.R. Nugmanov, R.K. Islamgaliev, Rev. Adv. Mater. Sci. 31, 157 (2012)

[40] K. Su, K.K. Deng, F.J. Xu, K.B. Nie, L. Zhang, X. Zhang, W.J. Li, Acta Metall. Sin. (Engl. Lett.) 28, 1015 (2015)

[41] X.G. Qiao, Y.W. Zhao, W.M. Gan, Y. Chen, M.Y. Zheng, K. Wu, N. Gao, M.J. Starink, Mater. Sci. Eng. A 619, 95 (2014)

[42] Y. Lu, A.R. Bradshaw, Y.L. Chiu, I.P. Jones, Mater. Sci. Eng. C 48, 480 (2015)

[43] Y. Song, E. Han, D. Shan, C.D. Yim, B.S. You, Corros. Sci. 60, 238 (2012)

[44] J. Chang, X. Guo, P. Fu, L. Peng, W. Ding, Electrochim. Acta 52, 3160 (2007)

[45] J. Liao, M. Hotta, N. Yamamoto, Corros. Sci. 61, 208 (2012)

[46] K.D. Ralston, N. Birbilis, Corrosion 66, 075005 (2010)

[47] Y. Zhang, J. Li, J. Li, J. Alloys Compd. 730, 458 (2018)

[48] M.I. Jamesh, G. Wu, Y. Zhao, D.R. McKenzie, M.M. Bilek, P.K. Chu, Corros. Sci. 91, 160 (2015) 